\title{
Why students travel abroad (and so many others do not): Exploring predictors and decision-making processes in study- related student travel
}

\author{
Ahlgrimm, Frederik ${ }^{a}$; Westphal, Andrea ${ }^{a}$; Heck, Sebastian ${ }^{a}$
}

${ }^{\mathrm{a}}$ Department of Education, Potsdam University, Germany

\begin{abstract}
Over the past few years, studying abroad and other educational international experiences have become increasingly highly regarded. Nevertheless, research shows that only a minority of students actually take part in academic mobility programs. But what is it that distinguishes those students who take up these international opportunities from those who do not? In this study we reviewed recent quantitative studies on why (primarily German) students choose to travel abroad or not. This revealed a pattern of predictive factors. These indicate the key role played by students' personal and social background, as well as previous international travel and the course of studies they are enrolled in. The study then focuses on teaching students. Both facilitating and debilitating factors are discussed and included in a model illustrating the decision-making process these students use. Finally, we discuss the practical implications for ways in which international, studyrelated travel might be increased in the future. We suggest that higher education institutions analyze individual student characteristics, offering differentiated programs to better meet the needs of different groups, thus raising the likelihood of disadvantaged students participating in academic international travel.
\end{abstract}

Keywords: internationalization; international academic mobility; studyrelated student travel; study abroad; teaching students; teacher education 


\section{Introduction}

According to the latest surveys, roughly a quarter of students enrolled in German universities take part in academic international travel during their studies. This includes studying abroad, internships, excursions, summer schools, projects and other study-related foreign stays. And yet, the vast majority of students in higher education do not take up these opportunities (Middendorf et al., 2017; Woisch \& Willige, 2015). The questions is: What is it that distinguishes those students who do take up these international opportunities from those who do not? Which factors facilitate or debilitate the decision to travel abroad for academic reasons? And is it true —as is frequently presumed in Germany - that teaching students are academically less mobile than peers who are not studying to become teachers?

A desire to address the challenges of a pluralistic, globalized society have resulted in calls for advanced internationalization in higher education in the European Union and in many countries, including Germany. Some studies, however, have warned against the danger of overestimating the positive effects of academic mobility. That being said, many empirical studies show that international travel often leads to positive outcomes. The range of studies on the effects of study-related stays abroad can be roughly categorized into three areas: General personality traits; foreign-language skills; and intercultural competencies and sensitivity (Streitwieser, Le, \& Rust, 2012).

\section{Empirical findings}

When German students travel abroad as part of their studies, the reasons for their trips breakdown as follows: Studies abroad (58\%), internships (30\%), excursions (10\%), language courses $(6 \%)$, summer schools $(4 \%)$, and projects $(4 \%)$ (Woisch \& Willige, 2015). What are the reasons for students to opt in or out of academic mobility? German and international studies have tackled this question using either qualitative approaches, such as interviews, or quantitative ones, mainly surveys. While some studies have looked into students' motives and perceived barriers (e.g. Cao, Zhu \& Meng, 2016), others have concentrated on personality traits (Zimmermann \& Neyer, 2013) or socio-economic characteristics (Finger \& Netz, 2016). These were used to predict the likelihood of students becoming academically mobile. Other studies examined how students with international experience differed from peers who were not academically mobile. This approach should be handled with caution, however, as it does not take into account whether disparities between the groups of mobile and non-mobile students existed before moving abroad or if those disparities emerged as a result of international travel. 


\subsection{Reasons for going: Students' motives for travelling abroad}

Why do students travel abroad as part of their studies? When asked to describe their motives, they emphasize positives such as encountering a different culture, improving their language abilities, and gathering new experiences, often referred to collectively as intercultural competence or intercultural sensitivity. The majority of students also mention that they believe it will have a positive effect in advancing their careers and will bring about gains in their subject field. In addition, many students see personal development as an important factor, believing it will lead to greater independence, as well as higher selfesteem and self-awareness (Woisch \& Willige, 2015). Only a small percentage indicate that they had to go abroad as a mandatory part of their studies (Heublein et al., 2008; Middendorf et al., 2017). In her qualitative study, based on 38 interviews with internationally mobile students, Ernlund (2014) developed a typology of four ideal types (Adventurer, Knowledge-Seeker, Escapee, and Cautious Academic), showing that mobile students' reasons for studying abroad differ significantly according to their motivations.

\subsection{Reasons for staying: Perceived obstacles to travel}

What keeps university students from travelling abroad, or even wanting to travel abroad in the first place? The most frequently mentioned reason is funding. Losing time and prolonging their studies is another apprehension In addition, social reasons like a long separation from a partner, friends, or family are often noted (Heublein et al., 2008; Middendorf et al., 2017; Souto-Otero, Huisman, Beerkens, de Wit \& Vujić, 2013; Woisch \& Willige, 2015). Many students in Germany, as well as a number of other countries, cite the fact that academic achievements in foreign countries are not recognized by their home institutions. Further hurdles mentioned include lacking foreign language skills and a lack of information and support from the home institution (Woisch \& Willige, 2015; Souto-Otero et al., 2013). Notably, students who wish to travel abroad perceive obstacles differently than those who do not wish to leave. The latter see much less sense in time spent abroad and are more likely to perceive losses through long separations from partners and friends. They also give their own laziness as a reason that they have not travelled abroad (Woisch \& Willige, 2015). Overall, both a lack of motivation to move abroad and a sense of the perceived hurdles can lead to students deciding against international academic mobilty.

\subsection{Who stays and who leaves? Differences between students who stay and those who go}

By taking individual and contextual characteristics into account, empirical studies can predict how likely a student will be to travel abroad as part of their studies. It is notable that female students are academically much more mobile than their male peers (Luo \& Jamieson-Drake, 2015; Stroud, 2010). This discrepancy cannot be fully explained by the fact that more females are enrolled in study courses with higher international exchange rates, such as economics or modern languages. Even within the same subjects, women tend 
to strive for international experiences more than men (Salisbury, Umbach, Paulsen \& Pascarella, 2009; Stroud, 2010).

Besides gender, family background is another important predictor of one's likelihood to travel. It is much more likely that students with an academic family background will travel abroad than students from non-academic families (Finger \& Netz, 2016; Lörz, Netz \& Quast, 2016; Salisbury et al., 2009). It would appear that economic concerns are not the only reason for this, with students from non-academic backgrounds unlikely to even consider the option of international study, as Salisbury et al. (2009) point out:

Our exploration of predisposition to study abroad reveals a complex interplay between socioeconomic status, social and cultural capital cumulated before college, and social and cultural capital gained. (p. 137)

Markers for this predisposition to study abroad can include previous international experiences, such as school exchanges and family trips abroad, as well as foreign language skills (Lörz et al., 2016). Students who spend more time with friends are more likely to plan to study abroad (Luo \& Jamieson-Drake, 2015), especially if those friends are from other countries or intend to travel abroad themselves (Van Mol \& Timmermann, 2014). Parental support seems matter, too, in the decision-making process (Petzold \& Peter, 2015).

\subsection{Do trainee teachers take up less international opportunities than other students?}

Because students in Germany have to choose a teacher-education track as soon as they enroll for their Bachelor program, the country's cohort of teaching students are often considered to be a special subgroup. In some circles, this subgroup is regarded as being less ambitious and risk-taking, thus resulting in less academic mobility. This is backed up by international research indicating that teacher candidates in other countries are also less likely to be academically mobile (Netz (2015). A closer look at German data samples, however, reveals that students enrolled for upper secondary teaching degrees (Gymnasium) travel abroad just as often as their peers in the same subjects who are not studying teaching - about $18 \%$ in 2009 . In contrast, teaching students studying to become elementary, lower secondary, or special educational teachers are less likely to take part in international activities. There are indications that this might me explained by a weaker socio-economic background of students enrolled in elementary education, though more research is needed to understand the differences properly. Students' teaching specialties also appear to be of great importance. We find high rates of academic mobilty in students enrolled in economics $(41 \%)$ and in modern languages, cultural subjects and sports $(31 \%)$, but not in science subjects and mathematics (23\%) (Woisch \& Willige, 2015).

Overall, teaching students seem not to differ significantly from their peers when it comes to academic mobility. Not surprisingly, their decision to travel is influenced by the same 
mechanisms of selection and self-selection as other students. The differences between higher secondary candidates and other pre-service teachers might be explained by the higher percentage of students from non-academic backgrounds in the latter group. In addition, the extremely detailed and inflexible curricula in German teacher education-and the resulting issues with the recognition of international qualifications - may also lead to lower participation rates in international academic mobility.

\section{Phases in decision-making}

Some authors posit that the decision to take part in international activities is a result of rational choice (Lörz et al., 2016), others (Carlson, 2013; Netz, 2015; Wernisch, 2016) believe that it is the result of a decision-making process. As Carlson (2013) states:

[We take] a processual perspective by asking how students become geographically mobile, thus perceiving studying abroad not as the result of a one-time choice but as the outcome of different long-term biographical and social processes and events. (p. 168)

Netz (2015) proposes a model with three phases, based on Gollwitzer's classic Rubicon model of action phases. We have augmented this approach, taking into account Wernisch's concept of thresholds that have to be crossed (2016) (see Figure 1).

Figure 1. Phases and thresholds in the decision-making process

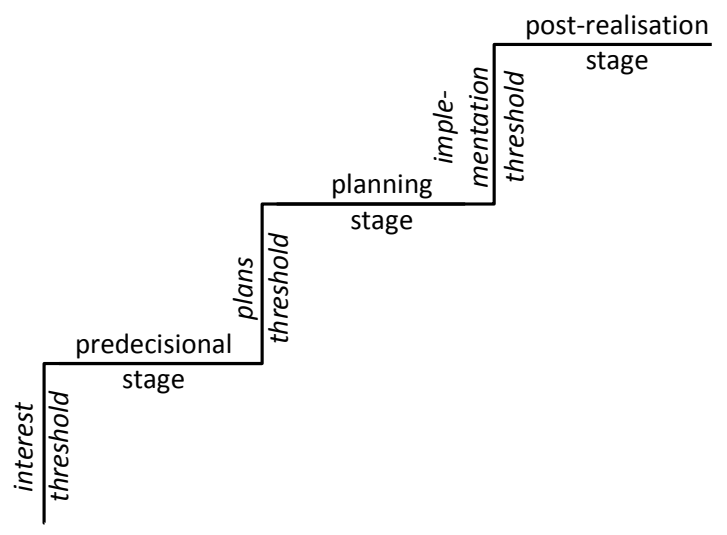

Figure inspired by Netz (2015) and Wernisch (2016)

After learning about existing opportunities, a student might become interested in academic mobility, developing a desire to take part in an initial, predecisional stage. In this very first phase, the individual's social background plays a key role (Lörz \& Krawietz, 2011; Netz, 2015). If someone decides to pursue the matter further and "their prior deliberation is 
replaced by a sense of determination to actually realize the former wish or desire that is now experienced as a firm goal" (Achtziger und Gollwitzer, 2007, p. 769), they find themselves in a planning stage, which is primarily shaped by practical considerations regarding applications, funding etc. Only if they succeed in finding solutions to these issues, will they finally implement their plan and travel abroad, thus finding themselves in a (post-)realisation stage. Wernisch's recent thesis (2016) describes in detail how different aspects shape the decision-making process during these stages.

\section{Discussion}

As described above, participation in academic mobility is highly selective and socially determined. In order to raise the share of students travelling abroad and make exchange programs not only available, but also attractive, to students from less privileged backgrounds, universities need to diversify their programs. It seems that programs such as Erasmus+ appear too requiring or risky for students who haven't or have hardly travelled abroad before. Thus we see a need for easily available, low-risk, low-stake programs, such as short-term excursions, as part of a student's study program, that could raise interest in and reduce the fear of international travel in those who have never been abroad before. The use of ICT to allow for virtual mobility should be a very good starting point to render international experiences possible without risks of financial or time losses. In addition, the mindsets and concerns of students with little or no previous international experience should be addressed when informing and advising them about academic mobility programs, possibly through peer reports from students with similar backgrounds. As financial reasons are often mentioned as reasons not to travel abroad, funding issues should also be addressed in early phases of information, as many students lack knowledge about scholarships and other sources of financial support. Finally, future research should aim to shed light on the potential advantages of academic mobility and highlight the outcomes, so that more students know what they can expect when travelling abroad — and what they will miss if they do not.

\section{References}

Achtziger, A. \& Gollwitzer, P. M. (2007). Rubicon model of action phases. In R. F. Baumeister \& K. D. Vohs (Hrsg.), Encyclopedia of social psychology (Bd. 2, S. 769770). Thousand Oaks, CA: Sage.

Cao, C., Zhu, C. \& Meng, Q. (2016). A survey of the influencing factors for international academic mobility of Chinese university students: International academic mobility of 
Chinese students. Higher Education Quarterly, 70(2), 200-220. https://doi.org/10.1111/hequ.12084

Carlson, S. (2013). Becoming a mobile student: a processual perspective on german degree student mobility. Population, Space and Place, 19(2), 168-180. https://doi.org/10.1002/psp.1749

Ernlund, M. (2014). La rencontre avec l'inconnu: Une enquête sur les motivations et les expériences des étudiants en mobilité. Journal of International Mobility, 2(14), 7-21. https://doi.org/10.3726/81704_7

Finger, C., \& Netz, N. (2016). Neue Ungleichheiten im deutschen Hochschulsystem? Internationale Studierendenmobilität zwischen 1991 und 2012. WZBrief Bildung, (34). Retrieved from https://www.wzb.eu/de/publikationen/wzbrief-bildung

Heublein, U., Hutzsch, C., \& Lörz, M. (2008). Auslandsmobilität deutscher Studierender. Ausmaß, Motive und Gründe des Desinteresses. Bildung und Erziehung, 61(4), 437450. https://doi.org/10.7788/bue.2008.61.4.437

Leutwyler, B. \& Lottenbach, S. (2011). Reflection on normality: The benefits of international student exchange for teacher education. In T. Goetz, G. Jaritz \& F. Oser (Hrsg.), Pains and gains of international mobility in teacher education (S. 59-77). Springer. Fassung vom 2011.

Lörz, M. \& Krawietz, M. (2011). Internationale Mobilität und soziale Selektivität: Ausmaß, Mechanismen und Entwicklung herkunftsspezifischer Unterschiede zwischen 1990 und 2005. Kölner Zeitschrift für Soziologie und Sozialpsychologie, 63(2), 185-205. https://doi.org/10.1007/s11577-011-0134-5

Lörz, M., Netz, N. \& Quast, H. (2016). Why do students from underprivileged families less often intend to study abroad? Higher Education, 72(2), 153-174. https://doi.org/10.1007/s10734-015-9943-1

Luo, J. \& Jamieson-Drake, D. (2015). Predictors of study abroad intent, participation, and college outcomes. Research in Higher Education, 56(1), 29-56. https://doi.org/10.1007/s11162-014-9338-7

Middendorff, E., Apolinarski, B., Becker, K., Bornkessel, P., Brandt, T., Heißenberg, S. \& Poskowsky, J. (2017). Die wirtschaftliche und soziale Lage der Studierenden in Deutschland 2016: 21. Sozialerhebung des Deutschen Studentenwerks - durchgeführt vom Deutschen Zentrum für Hochschul- und Wissenschaftsforschung. Berlin: Bundesministerium für Bildung und Forschung [BMBF].

Netz, N. (2015). What deters students from studying abroad? Evidence from four European countries and its implications for higher education policy. Higher Education Policy, 28(2), 151-174. https://doi.org/10.1057/hep.2013.37 
Petzold, K., \& Peter, T. (2015). The social norm to study abroad: Determinants and effects. Higher Education, 69(6), 885-900. https://doi.org/10.1007/s10734-014-9811-4

Salisbury, M. H., Umbach, P. D., Paulsen, M. B. \& Pascarella, E. T. (2009). Going global: Understanding the choice process of the intent to study abroad. Research in Higher Education, 50(2), 119-143. https://doi.org/10.1007/s11162-008-9111-x

Souto-Otero, M., Huisman, J., Beerkens, M., de Wit, H. \& Sunčica Vujić. (2013). Barriers to international student mobility: Evidence from the Erasmus program. Educational Researcher, 42(2), 70-77. https://doi.org/10.3102/0013189X12466696

Streitwieser, B. T., Le, E., \& Rust, V. (2012). Research on study abroad, mobility, and student exchange in comparative education scholarship. Research in Comparative and International Education, 7(1), 5-19. https://doi.org/10.2304/rcie.2012.7.1.5

Stroud, A. H. (2010). Who plans (not) to study abroad? An examination of U.S. student intent. Journal of Studies in International Education, 14(5), 491-507. https://doi.org/10.1177/1028315309357942

Van Mol, C. \& Timmerman, C. (2014). Should I stay or should I go? An analysis of the determinants of intra-European student mobility. Population, Space and Place, 20(5), 465-479. https://doi.org/10.1002/psp.1833

Wernisch, D. V. (2016). Internationalization and student mobility in teacher education: Internationalization models, diffusion barriers, and recommendations for policy and higher education institutions (Dissertation). Pädagogische Hochschule Freiburg, Freiburg.

Woisch, A. \& Willige, J. (2015). Internationale Mobilität im Studium 2015. Ergebnisse der fünften Befragung deutscher Studierender zur studienbezogenen Auslandsmobilität. (Projektbericht). Hannover: Deutscher Akademischer Austauschdienst [DAAD].

Zimmermann, J. \& Neyer, F. J. (2013). Do we become a different person when hitting the road? Personality development of sojourners. Journal of Personality and Social Psychology, 105(3), 515-530. https://doi.org/10.1037/a0033019 